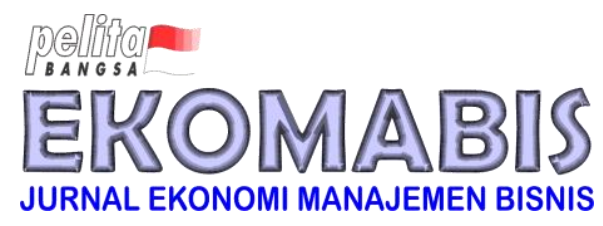

\title{
Pengaruh Ukuran Dewan Komisaris, Komite Audit, dan Kepemilikan Institusional Terhadap Kinerja Keuangan Perusahaan
}

Submit: 26 Aug 2020; Review: 29 Aug 2020; Accepted: 05 Dec 2020; Publish: 07 Dec 2020

\section{Nani Hartati ${ }^{1}$}

\begin{abstract}
ABSTRAK
Dalam mencapai tujuan, suatu perusahaan tentunya harus memperhatikan kinerja keuangan yang diukur dengan rasio keuangan. Tujuan dari penelitian ini untuk mengetahui pengaruh ukuran dewan komisaris, komite audit dan kepemilikan institusional terhadap kinerja keuangan perusahaan pada sektor Property, Real Estate dan Building Construction yang terdaftar di Bursa Efek Indonesia (BEI) tahun 20162018. Terdapat 43 perusahaan yang memenuhi kriteria sebagai sampel penelitian. Metode analisis yang digunakan adalah analisis regresi linier berganda. Dari hasil penelitian diketahui ukuran dewan komisaris dan komite audit tidak berpengaruh terhadap kinerja keuangan perusahaan, sedangkan kepemilikan institusional berpengaruh terhadap kinerja keuangan perusahaan.
\end{abstract}

Kata Kunci: Kinerja Keuangan, Dewan Komisaris, Komite Audit, Kepemilikan Institusional

\begin{abstract}
In achieving goals, a company must pay attention to financial performance as measured by financial ratios. The purpose of this study is to see the influence of the influence of the board of commissioners, audit committee and institutional ownership on the company's financial performance in the Property, Real Estate, and Building Construction sectors listed on the Indonesian Stock Exchange (BEI) 2016-2018. There are 43 companies that meet the criteria as research samples. The analytical method used is multiple linear regression analysis. It is known that the size of the board of commissioners and audit committee has no effect on the company's financial performance, while institutional ownership has an effect on the company's financial performance.
\end{abstract}

Keywords: Financial Performance, Board of Commissioners, Audit Committee, Institutional Ownership

1 Universitas Pelita Bangsa; nani.hartati@pelitabangsa.ac.id 


\section{Pendahuluan}

Laporan keuangan adalah suatu informasi yang menggambarkan posisi keuangan dan kinerja keuangan suatu perusahaan. Tujuan laporan keuangan adalah memberikan suatu gambaran informasi terkait posisi keuangan, kinerja keuangan, dan arus kas perusahaan bagi pemakai laporan keuangan dalam mengambil suatu keputusan (PSAK, 2018:3). Return on Asset (ROA) adalah rasio keuangan yang mengukur kemampuan perusahaan dalam menghasilkan laba atau keuntungan dengan memaksimalkan asset yang dimilikinya. Rasio ini menggambarkan kinerja perusahaan dalam menghasilkan laba dari setiap rupiah asset yang digunakan dalam kegiatan operasi perusahaan (Fahmi, 2012).

Berdasarkan data perhitungan rata - rata rasio Return on Asset (ROA) selama periode tahun 2016-2018 untuk perusahaan sektor Property, Real Estate dan Building Construction yang terdaftar di Bursa Efek Indonesia (BEI), menunjukkan bahwa perusahaan sektor Property, Real Estate dan Building Construction yang menggunakan rasio Return on Asset (ROA) mengalami penurunan dari tahun 2016-2018. Karena penurunan tersebut dapat mengakibatkan para investor berpotensi untuk menanamkan modalnya ke sektor yang lain. Kinerja keuangan perusahaan sektor Property, Real Estate dan Construction Building selama 3 tahun terakhir tidak terlalu menggembirakan.

Good Corporate Governance adalah suatu sistem pengelolaan perusahaan yang bertujuan untuk meningkatkan kinerja keuangan perusahaan, dan melindungi kepentingan pemegang saham untuk mencapai tujuan perusahaan (Sari \& Setyowati, 2017). Mekanisme Good Corporate Governance terdiri dari mekanisme eksternal dan internal (Sutedi, 2011). Mekanisme internal Good Corporate Governance dipengaruhi oleh faktor internal perusahaan yang diantaranya adalah kepemilikan institusional, kepemilikan manajerial, dewan komisaris, dan komite audit.

Dewan Komisaris menurut POJK Nomor 33 /POJK.04/2014 merupakan organisasi perusahaan bertugas untuk melakukan pengawasan secara umum dan/atau khusus sesuai dengan peraturan serta memberikan nasihat kepada direksi. Dewan komisaris bertanggung jawab dalam control manajemen perusahaan(Rahnawati,dkk, 2017). Dengan demikian keberadaan dewan komisaris untuk memastikan setiap dewan menjalankan tugasnya dengan baik dan tersistem. Dan menurut POJK Nomor 55 /POJK.04/2015 Komite Audit ialah organisasi yang dibentuk oleh Dewan Komisaris dan bertanggung jawab dalam membantu tugas dan fungsi Dewan Komisaris. Komite ini bertugas untuk melaksanakan pengawasan internal terkait terlaksananya audit, manajemen risk, proses laporan keuangan dan implementasi GCG. Pengukuran Komite Audit dapat dihitung dengan menggunakan total jumlah anggota Komite Audit di dalam suatu perusahaan.

Kepemilikan Institusional dapat dikatakan sebagai kepemilikan saham pada akhir tahun yang dimiliki oleh pihak diluar perusahaan yang berbentuk institusi, lembaga ataupun bentuk lainnya (Widiastuti et al, 2013). Pengukuran 
Kepemilikan Institusional ini dapat dihitung dengan total jumlah saham institusional dibandingkan dengan total jumlah saham yang beredar. Sedangkan kepemilikan manajerial merupakan jumlah saham yang dimiliki oleh manajemen perusahaan yang dapat diukur dengan menghitung persentase saham yang dimiliki oleh manajemen perusahaan dengan seluruh jumlah saham perusahaan yang beredar.

\section{Metodologi}

Populasi dalam penelitian ini sebanyak 83 perusahaan sektor Property, Real Estate dan Building Construction yang terdaftar di Bursa Efek Indonesia (BEI) periode pengamatan tahun 2016-2018. Dengan penentuan sample yang digunakan adalah teknik Purposive Sampling. Dalam penelitian ini yang menjadi karakteristik pertimbangan untuk pengambilan sampel sebagai berikut:

a. Perusahaan sektor Property, Real Estate dan Building Construction yang terdaftar di Bursa Efek Indonesia (BEI) tahun 2016-2018.

b. Perusahaan sektor Property, Real Estate dan Building Construction yang menerbitkan laporan tahunan (Annual Report) selama tahun 2016-2018.

c. Perusahaan sektor Property, Real Estate dan Building Construction yang tidak mengalami kerugian selama tahun 2016-2018

d. Perusahaan yang memiliki kelengkapan data laporan tahunan (Annual Report) yang berkaitan dengan variabel yang digunakan dalam penelitian ini.

Dalam penelitian ini, analisis data menggunakan Eviews 11.0. hasil pemilihan regresi data panel dilakukan melalui beberapa tahap. Pertama melakukan pemilihan model yang paling tepat. Berdasarkan Uji Chow yang dilakukan model yang paling tepat adalah Fixed Effect Model yang ditunjukan oleh nilai probabilitas Cross section F sebesar $0.0023<0.05$. Selanjutnya dilakukan Uji Housman untuk memastikan model mana yang paling tepat. Berdasarkan uji Housman model yang paling tepat digunakan adalah Fixed Effect Model yakni dengan nilai probabilitas Cross Section Random $0.0481<0.05$. Berdasarkan kedua uji tersebut, model yang terpilih adalah fixed effect model, maka tidak perlu dilakukan lagi Uji Langrang Multiplier namun perlu dilakukan Uji Asumsi klasik. Uji asumsi klasik yang digunakan adalah uji multikolinieritas dan heterokedastisitas. Dari hasil uji multikolenieritas diperoleh hasil koefisien korelasi < 0,9 yang artinya tidak ada gejala multikolenieritas. Untuk uji heteroskedastisitas dengan melakukan transformasi logaritma diperoleh hasil probabilitas $0.0000<0.05$ maka disimpulkan tidak ada gejala heterokedastisitas dalam penelitian ini. Persamaan model regresi linier berganda dengan menggunakan data panel dalam penelitian ini adalah sebagai berikut:

$Y t i=a+B 1 X 1 t i+\beta 2 X 2 t i+\beta 3 X 3 t i+e$

Hipotesis diterima jika memenuhi dua kriteria yaitu nilai koefisien regresi tidak sama dengan nol dan nilai sig. $t$ kurang dari 0,05. 
Operasional variable merupakan konsep variable yang digunakan dalam penelitian ini, sebagai mana tercantum dalam table 1.

Tabel 1. Operasionalisasi Variabel

\begin{tabular}{|c|c|c|}
\hline Variabel & Konsep & Indikator \\
\hline Kinerja Keuangan & $\begin{array}{l}\text { Kinerja keuangan merupakan suatu } \\
\text { gambaran kondisi keuangan perusahaan } \\
\text { dengan menganalisis laporan keuangan } \\
\text { yang diukur dengan rasio keuangan, } \\
\text { sehingga dapat diketahui kondisi keungan } \\
\text { perusahaan dalam suatu periode tertentu. } \\
\text { (Prasinta, 2012). }\end{array}$ & $\begin{array}{c}\mathrm{ROA}= \\
\frac{\text { Net } \text { Profit }}{\text { Total Assets }} \times 100 \%\end{array}$ \\
\hline $\begin{array}{l}\text { Dewan } \\
\text { Komisaris(DK) }\end{array}$ & $\begin{array}{l}\text { Dewan Komisaris adalah suatu organisasi } \\
\text { perusahaan bertugas untuk melakukan } \\
\text { pengawasan secara umum dan/atau } \\
\text { khusus sesuai dengan peraturan serta } \\
\text { memberikan nasihat kepada Direksi } \\
\text { (POJK, 2014). }\end{array}$ & $\begin{array}{c}\text { DK }= \\
\sum \text { Anggota DK }\end{array}$ \\
\hline Komite Audit (KA) & $\begin{array}{l}\text { Komite Audit adalah suatu organisasi } \\
\text { yang dibentuk oleh Dewan Komisaris dan } \\
\text { bertanggung jawab dalam membantu } \\
\text { tugas dan fungsi Dewan Komisaris (POJK, } \\
\text { 2015). }\end{array}$ & $\mathrm{KA}=\sum$ Anggota $\mathrm{KA}$ \\
\hline Kepemilikan & Kepemilikan Institusional adalah & \\
\hline Institusional (KI) & $\begin{array}{l}\text { dimiliki oleh pihak diluar perusahaan } \\
\text { yang berbentuk institusi, lembaga } \\
\text { ataupun bentuk lainnya (Widiastuti et al, } \\
\text { 2013). }\end{array}$ & $\begin{array}{l}\mathrm{KI}= \\
\frac{\sum \text { Saham Institusional }}{\sum \text { Saham Beredar }}\end{array}$ \\
\hline
\end{tabular}

\section{Hasil}

Hasil analisis regresi yang diperoleh dari regresi data panel dapat kita lihat pada table berikut:

Tabel. Analisis Regresi Linear berganda

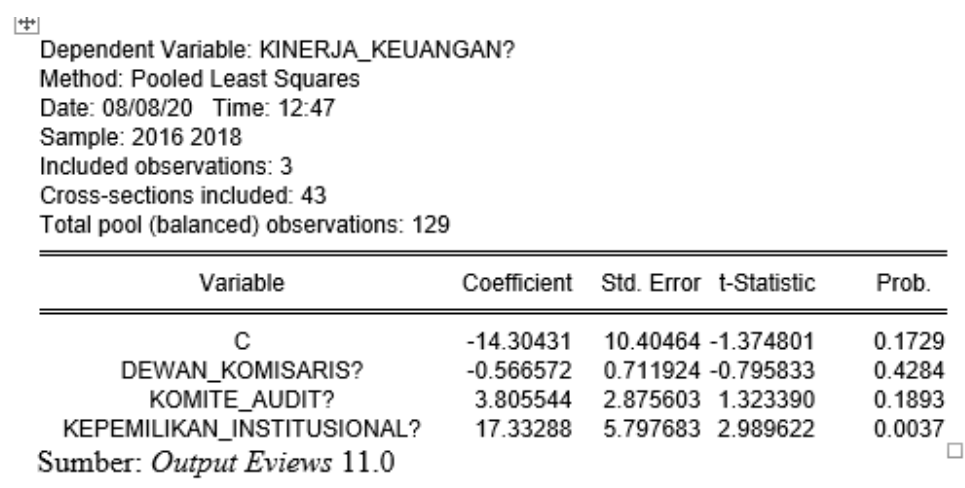


Berdasarkan hasil tersebut maka dihasilkan persamaan model regresi sebagai berikut:

Kinerja Keuangan $=-14.30431-0,566572 \mathrm{DK}+3.805544 \mathrm{KA}+17.33288 \mathrm{KI}$

Yang artinya apabila variable independen yang diteliti bernilai 0, maka nilai Kinerja keuangan sebesar konstanta yaitu -14.30431. Apabila nilai DK naik 1 satuan, maka berdampak pada penurunan kinerja keuangan sebesar 0,566572. Begitu juga dengan variable KA, bila KA mengalami peningkatan 1 satuan maka kinerja keuangan akan naik sebesar 3,805544. Dan apabila KI mengalami kenaikan 1 satuan maka akan menyebabkan kinerja keuangan naik sebesar 17.33288. Berdasarkan table tersebut maka pengujian hipotesis penelitian ini adalah sebagai berikut:

Dewan Komisaris Pengaruh positif terhadap Kinerja keuangan perusahaan. Berdasarkan uji $\mathrm{t}$ tersebut diatas menunjukan nilai prob sebesar $0.4282>$ tingkat signifikansi 5\%, maka dapat disimpulkan $\mathrm{H}_{0}$ diterima dan $\mathrm{H}_{1}$ ditolak. Artinya Dewan Komisaris tidak berpengaruh sigifikan terhadap kinerja keuangan.

Komite Audit berpengaruh positif terhadap kinerja keuangan. Berdasarkan dari uji $\mathrm{t}$ diatas, nilai prob sebesar $0.1893>$ tingkat signifikansi 5\%, maka dapat disimpulkan $\mathrm{H}_{0}$ diterima dan $\mathrm{H}_{1}$ ditolak. Artinya Komite Audit tidak berpengaruh terhadap kinerja keuangan.

Kepemilikan Institusional berpengaruh positif terhadap Kinerja Keuangan Perusahaan. Berdasarkan table diatas, nilai prob $0.0037>$ tingkat signifikasi 5\%, maka dapat disimpulkan H0 ditolak dan H1 diterima, yang artinya bahwa Kepemilikan Institusional berpengaruh positif dan signifikan terhadap Kinerja Keuangan

Selanjutnya dilakukan uji simultan (Uji F) untuk mengetahui pengaruh variable independen secara simultan. Hasil uji F sebagaimana tersaji sebagai berikut:

Tabel Hasi Uji F

\begin{tabular}{lllr}
\hline \hline Cross-section fixed (dummy variables) & & \\
\hline \hline Root MSE & 3.210453 & R-squared & 0.549108 \\
Mean dependent var & 5.140698 & Adjusted R-squared & 0.304649 \\
S.D. dependent var & 4.799767 & S.E. of regression & 4.002415 \\
Akaike info criterion & 5.883880 & Sum squared resid & 1329.604 \\
Schwarz criterion & 6.903658 & Log likelihood & -333.5102 \\
Hannan-Quinn criter. & 6.298236 & F-statistic & 2.246217 \\
Durbin-Watson stat & 2.685108 & Prob(F-statistic) & 0.000712 \\
\hline \hline
\end{tabular}

Sumber: Output Eviews 11.0

Berdasarkan table tersebut diketahui nilai prob sebesar $0.000712<$ tingkat signifikansi 5\%, maka dapat diartikan bahwa variable Dewan Komisaris, Komite Audit dan Kepemilikan Institusional secara simultan berpengaruh terhadap kinerja perusahaan. 


\section{Pembahasan}

Dewan komisaris tidak berpengaruh terhadap kinerja keuangan perusahaan. Artinya bahwa semakin meningkatnya Dewan Komisaris maka belum tentu menurunkan kinerja keuangan perusahaan. Hasil penelitian ini dapat terjadi karena banyak dan sedikitnya jumlah dewan komisaris maka tetap menghasilkan pengawasan yang sama terhadap segala aktivitas manajemen bagi perusahaan sehingga tidak berpengaruh terhadap kinerja keuangan perusahaan.

Hasil penelitian ini sejalan dengan Diyanty \& Yusniar (2019), Wardani \& Zulkifli (2017), Tertius \& Christiawan (2015), Tussakdiah et al (2016), dan Riyadi \& Santoso (2018) bahwa dewan komisaris tidak berpengaruh terhadap kinerja keuangan perusahaan. Maka bisa disimpukan bahwa keberadaan Dewan Komisaris pada fungsi pengawasan belum terlaksana dengan baik sehingga banyak dan sedikitnya Dewan Komisaris tidak mempengaruhi terhadap Kinerja Keuangan Perusahaan.

Komite Audit tidak berpengaruh terhadap Kinerja Keuangan Perusahaan. Artinya bahwa semakin meningkatnya Komite Audit belum tentu meningkatkan Kinerja Keuangan Perusahaan. Hal ini menunjukkan bahwa banyak atau sedikitnya jumlah Komite Audit tidak berpengaruh terhadap Kinerja Keuangan Perusahaan. Hasil penelitian ini dapat terjadi banyaknya jumlah Komite Audit tidak menjamin pengawasan terhadap Kinerja Keuangan Perusahaan dan adanya Komite Audit di dalam perusahaan hanya sebagai syarat bahwa perusahaan wajib memiliki Komite Audit minimal 3 orang.

Hasil penelitian ini sejalan dengan Jaya et al (2019), Wardani \& Zulkifli (2017), Diyanty \& Yusniar (2019), Eksandy (2018), Sembiring \& Seragih (2019), Aini et al (2017), Azis \& Hartono (2017), Tussakdiah et al (2016), Dewi \& Tenaya (2017), Saputri et al (2017), dan Rahmawati et al (2017) bahwa dan Komite Audit tidak berpengaruh terhadap Kinerja Keuangan. Maka dapat dikatakan bahwa Komite Audit dibentuk hanya atas dasar regulasi pemerintah yang mengharuskan setiap perusahaan untuk membentuk Komite tambahan yang bertugas untuk membantu tugas pengawasan.

Kepemilikan institusional berpengaruh positif terhadap kinerja keuangan perusahaan. Artinya bahwa semakin meningkatnya jumlah saham yang dimiliki pihak institusional maka dapat meningkatkan kinerja keuangan perusahaan. Hal ini menunjukan bahwa banyak dan sedikitnya jumlah saham yang beredar yang dimiliki pihak institusional dapat mempengaruhi kinerja keuangan perusahaan. Hasil penelitian ini dapat terjadi karena adanya pihak institusional dalam suatu perusahaan dapat melakukan pengawasan lebih optimal untuk menghindari adanya kecurangan yang dilakukan manajemen dalam suatu perusahaan.

Hasil Penelitian ini sejalan dengan Saputri et al (2019), Aini et al (2017), dan Dewi \& Tenaya (2017) menyatakan bahwa Kepemilikan Institusional berpengaruh terhadap kinerja keuangan perbankan. Maka disimpulkan bahwa dengan adanya kepemilikan institusional dalam suatu perusahaan dapat melakukan 
pengawasan dengan baik karena pihak Institusional lebih memberikan tekanan kepada perusahaan agar dapat mencapai target yang diharapkan

Dewan Komisaris, Komite Audit dan Kepemilikan Institusional berpengaruh terhadap Kinerja Keuangan Perusahaan. Artinya bahwa semakin meningkatnya jumlah Dewan Komisaris, Komite Audit dan Kepemilikan Institusional secara simultan dapat meningkatkan Kinerja Keuangan Perusahaan. Hal ini menunjukan bahwa Dewan Komisaris, Komite Audit dan Kepemilikan Institusional secara simultan dapat mempengaruhi Kinerja Keuangan Perusahaan. Hal ini dapat terjadi karena dengan adanya pengawasan dari pihak internal dan pihak eksternal perusahaan maka dapat lebih fokus dalam mengawasi segala aktifitas manajemen dalam suatu perusahaan dan dapat meminimalisir kecurangan yang dilakukan oleh pihak manajemen sehinggga dapat meminimalisir kecurangan yang dilakukan oleh pihak manajemen.

Hasil penelitian ini sejalan dengan Irma (2019) dan Saputri et al (2019) yang memberikan pendapat bahwa dengan adanya Dewan Komisaris, Komite Audit dan Kepemilikan Institusional dalam suatu perusahaan dapat mengendalikan dan mengawasi perusahaan untuk lebih meningkatkan kinerja manajemen dan lebih meningkatkan keuntungan suatu perusahaan sehingga dapat memaksimalkan Kinerja Keuangan Perushaan.

\section{Kesimpulan}

Dewan komisaris tidak berpengaruh terhadap kinerja keuangan perusahaan. Artinya bahwa semakin meningkatnya Dewan Komisaris maka belum tentu menurunkan kinerja keuangan perusahaan. Komite Audit tidak berpengaruh terhadap Kinerja Keuangan Perusahaan. Artinya bahwa semakin meningkatnya Komite Audit belum tentu meningkatkan Kinerja Keuangan Perusahaan. Dan Kepemilikan institusional berpengaruh positif terhadap kinerja keuangan perusahaan. Artinya bahwa semakin meningkatnya jumlah saham yang dimiliki pihak institusional maka dapat meningkatkan kinerja keuangan perusahaan. Kemudian secara simultan Dewan Komisaris, Komite Audit dan Kepemilikan Institusional berpengaruh terhadap Kinerja Keuangan Perusahaan. Artinya bahwa semakin meningkatnya jumlah Dewan Komisaris, Komite Audit dan Kepemilikan Institusional secara simultan dapat meningkatkan Kinerja Keuangan Perusahaan.

\section{DAFTAR PUSTAKA}

Aini, Ayu Nur, Edi Budi santoso Santoso, and Isnani. 2017. “, Komite Audit, Struktur Modal, Ukuran Perusahaan Dan Leverage Terhadap Kinerja Keuangan (Studi Pada Perusahaan Manufaktur Sektor Industri Barang ....” Jurnal.Unpand.Ac.Id: 1-18. http://jurnal.unpand.ac.id/index.php/AKS/article/download/796/772. 
Azis, Abdul, and Ulil Hartono. 2017. "Pengaruh Good Corporate Governance, Struktur Modal, Dan Leverage Terhadap Kinerja Keuangan Perusahaan Pada Sektor Pertambangan Yang Terdaftar Di Bursa Efek Indonesia Tahun 2011-2015.” Jurnal Imu Manajemen 5(3): 1-13.

Basuki, Agus Tri, and Nano Prawoto. 2016. Analisis Regresi Dalam Penelitian Ekonomi Dan Bisnis. Jakarta: Raja Grafindo Persada.

“Bursa Efek Indonesia.” 2020. www.idx.co.id.

Caesario, Emanuel Berkah. 2018. "Sektor Properti Diprediksi Masih Lesu." https://market.bisnis.com/read/20180109/192/724951/2018-sektor-propertidiprediksi-masih-lesu.

Dewi, Pande Putu Enda Rastiana, and Agus Indra Tenaya. 2017. "Pengaruh Penerapan GCG Dan Ukuran Perusahaan Terhadap Kinerja Keuangan Perbankan Di BEI Periode 2013-2016.” E-Jurnal Akuntansi Universitas Udayana 21(1): 310-29.

Diyanty, Mira, and Meina Wulansari Yusniar. 2019. "Pengaruh Mekanisme Good Corporate Governance Terhadap Kinerja Keuangan Padaperbankan Yang Terdaftar Di Bursa Efek Indonesia (BEI).” Jurnal Wawasan Manajemen 7(1): 49-65.

Eksandy, Arry. 2018. "Pengaruh Good Corporate Governance Terhadap Kinerja Keuangan Pada Perbankan Syariah Indonesia.” Jurnal Akuntansi 5(1): 1-10.

Fahmi, Irham. 2012. Analisis Laporan Keuangan. Bandung: Alfabeta.

Ghozali, Imam. 2017. Analisis Multivariat Dan Ekonometrika. Semarang: Universitas Diponegoro.

Gujarati, Damodar, and Dawn Porter. 2012. Dasar-Dasar Ekonometrika. Jakarta: Salemba Empat.

Ikatan Akuntansi Indonesia. 2018. Pernyataan Standar Akuntansi Keuangan. Jakarta: Agrikultural.

Irma, Amelya Dwi Ade. 2019. "Pengaruh Komisaris, Komite Audit, Struktur Kepemilikan, Size, Dan Leverage Terhadap Kinerja Keuangan Perusahaan Properti, Perumahan Dan Konstruksi 2013-2017.” Jurnal Ilmu Manajemen 7(3): 697-712.

Jaya, Fenti Arista, Ratna Wijayanti D P, and M Wimbo Wiyono. 2019. "Pengaruh Good Corporate Governance Terhadap Kinerja Keuangan ( Studi Pada Perusahaan Sub Sektor Perbankan Yang Terdaftar Di BEI Tahun 2015 - 2017 ).” : 16-21.

Komite Nasional Kebijakan Governance. 2006. "Pedoman Umum Good Corporate Governance Indonesia."

Menteri Negara Perumahan Rakyat. 1995. Keputusan Menteri Negara Perumahan 
Rakyat Selaku Ketua Badan Kebijaksanaan Dan Pengendalian Pembangunan Perumahan Dan Pemukiman Nasionan Nomor 06/KPTS/BPK4N/1995 Tentang Pedoman Pembuatan Akta Pendirian, Anggaran Dasar Anggaran Rumah Tangga Perhimpunan Pe. Jakarta.

Otoritas Jasa Keuangan. 2014. Peraturan Otoritas Jasa Keuangan Nomor 33 /POJK.04/2014 TENTANG Direk Dan Dewan Komisaris Emiten Atau Perusahaan Publik. Jakarta.

- 2015. Peraturan Otoritas Jasa Keuangan Nomor 55 /POJK.04/2015 TENTANG Pembentukan Dan Pedoman Pelaksanaan Kerja Komite Audit. Jakarta.

Permanasari, Wien Ika. 2010. PENGARUH KEPEMILIKAN MANAJEMEN, KEPEMILIKAN INSTITUSIONAL, DAN CORPORATE SOCIAL RESPONSIBILITY TERHADAP NILAI PERUSAHAAN.

Prasinta, Dian. 2012. "Pengaruh Good Corporate Governance Terhadap Kinerja Keuangan." Accounting Analysis Journal 1(2): 1-7. http://journal.unnes.ac.id/sju/index.php/aaj.

Prodi Universitas Pelita Bangsa. 2020. Pedoman Penulisan Karya Ilmiah :Tugas Akhir, Skripsi, Dan Tesis. Bekasi: Universitas Pelita Bangsa.

Pujasukum, Desi Pipian, and Sinarti. 2019. "The Effect of Good Corporate Governance Mechanism On The Financial Performance of Banking Companies Listed In Stock Exchange Indonesia 2012-2016." Journal of Applied Managerial Accounting 3(2): 273-87.

Rahmawati, I.A, Brady Rikumahu, and Vaya Juliana Dillak. 2017. "Pengaruh Dewan Direksi, Dewan Komisaris, Komite Audit Dan Corporate Social Responsibility Terhadap Kinerja Keuangan Perusahaan.” Jurnal Akuntansi dan Ekonomi 2(2): 54 70.

Riyadi, Slamet, and Cahyo Budi Santoso. 2018. "The Influence of Board of Commissioners, Board of Directors, Board of Commissioners Independent Audit Committee and Board of Trustees to Financial Performance Islamic Banking (Case Study on Islamic Bank Period in 2011-2013)." Archives of Business Research 6(5): 168-77.

Saputri, Nadya Ayu, Rochmi Widayanti, and Ratna Damayanti. 2019. "Analisis Penerapan Good Corporate Governance Terhadap Kinerja Keuangan Pada Perusahaan Perbankan Yang Terdaftar Di Bursa Efek Indonesia Periode 20142017." Edumonika 3(2): 352-63.

Sekaran, Uma, and Bougie Roger. 2013. Research Methods for Business: A Skill-Building Approach. New York: Jhon Wiley@ Sons.

Sembiring, Christin Yan Br, and Afni Eliana Saragih. 2019. "Pengaruh Komisaris Independen Dan Komite Audit Terhadap Kinerja Keuangan Terdaftar Di Bursa Efek Indonesia.” Jrak 5(2): 229-42. 
Sutedi, Andrian. 2011. Good Corporate Governance. Jakarta: Sinar Grafika.

Sutojo, Siswanto, and John Aldridge. 2005. Good Corporate Governance. Jakarta: Damar Media Pustaka.

Tertius, Melia Agustiana, and Yulius Jogi Christiawan. 2015. "Pengaruh Good Corporate Governance Terhadap Kinerja Perusahaan Pada Sektor Keuangan." Bussines Accounting Review 3: 224-32.

Tussakdiah, Halimah, Kamaliah, and Novita Indrawati. 2016. "Pengaruh Good Corporate Governance Terhadap Kinerja Keuangan.” Jurnal Ekonomi 24(3): 89-106..

Widiastuti, Marselina, Pranata Madiastuti, and Eddy Siranta. 2013. "Dividend Policy and Foreign Ownership.” Simposium Nasional Akuntansi XVI: 3401-23.

Wiranata, Y, and Y Nugrahanti. 2013. "Pengaruh Struktur Kepemilikan Terhadap Profitabilitas Perusahaan Manufaktur Di Indonesia. Jurnal Akuntansi Dan Keuangan.” Jurnal Akuntansi dan Keuangan 15(1): 15-26. 